\title{
Interaction of impurity atoms of light elements with self-interstitials in fcc metals
}

\author{
I. V. Zorya ${ }^{1}$, G. M. Poletaev², R. Y. Rakitin³, M. A. Ilyina ${ }^{4}$, M. D. Starostenkov² \\ †gmpoletaev@mail.ru \\ ${ }^{1}$ Siberian State Industrial University, 25 Bardin Av., Novokuznetsk, 654007, Russia \\ ${ }^{2}$ Altai State Technical University, 46 Lenin Av., Barnaul, 656038, Russia \\ ${ }^{3}$ Altai State University, 61 Lenin Av., Barnaul, 656049, Russia \\ ${ }^{4}$ Financial University under the Government of the Russian Federation, 54 Lenin Av., Barnaul, 656036, Russia
}

\begin{abstract}
The interaction of impurity atoms of light elements $\mathrm{C}, \mathrm{N}, \mathrm{O}$ with self-interstitials in fcc metals $\mathrm{Ni}, \mathrm{Ag}$ and $\mathrm{Al}$ was studied by the molecular dynamics method. It is shown that the self-interstitial atom in fcc metals migrates through at least two mechanisms: by the displacement and rotation of the $<100>$ dumbbell and by the crowdion mechanism. The first mechanism is characterized by broken trajectories of atomic displacements, the second - by straight ones along close-packed directions in the crystal. The binding energies of impurity atoms with self-interstitials in $\mathrm{Ni}, \mathrm{Ag}$ and $\mathrm{Al}$ have been calculated. It is shown that impurity atoms are effective "traps" for interstitial atoms that migrate relatively quickly in a crystal. When a self-interstitial atom and an impurity atom interact, the interstitial atom forms a dumbbell configuration with the axis along the $<100>$ direction, and the impurity atom is located in the nearest octahedral pore. To analyze the effect of impurities on the diffusion mobility of interstitial atoms, we calculated the activation energy of migration of the interstitial atom in pure metals and metals containing $10 \%$ of impurity atoms. It was found that the mobility of interstitial atoms is significantly reduced due to the presence of impurities in the metal. At the same time, the contribution of the crowdion mechanism also decreased.
\end{abstract}

Keywords: molecular dynamics, metal, self-interstitial, impurity, binding energy.

УДК: 538.911

\section{Взаимодействие примесных атомов легких элементов с собственными межузельными атомами в ГЦК металлах}

\author{
Зоря И. В. ${ }^{1}$, Полетаев Г. М. ${ }^{2}$, Ракитин Р. Ю. ${ }^{3}$, Ильина М. А. ${ }^{4}$, Старостенков М. Д. ${ }^{2}$
}

${ }^{1}$ Сибирский государственный индустриальный университет, пр. Бардина, 25, Новокузнецк, 654007, Россия ${ }^{2}$ Алтайский государственный технический университет им. И. И. Ползунова, пр. Ленина, 46, Барнаул, 656038, Россия

${ }^{3}$ Алтайский государственный университет, пр. Ленина, 61, Барнаул, 656049, Россия

${ }^{4}$ Финансовый университет при Правительстве РФ, пр. Ленина, 54, Барнаул, 656036, Россия

Методом молекулярной динамики проведено исследование взаимодействия примесных атомов легких элементов С, $\mathrm{N}, \mathrm{O}$ с собственными межузельными атомами в ГЦК металлах $\mathrm{Ni}, \mathrm{Ag}$ и Al. Показано, что собственный межузельный атом в ГЦК металлах мигрирует посредством, как минимум, двух механизмов: смещения и поворота гантели $<100>$ и краудионного механизма. Для первого механизма характерны ломаные траектории смещений атомов, для второго прямые вдоль плотноупакованных направлений в кристалле. Рассчитаны энергии связи примесных атомов с собственными межузельными атомами в $\mathrm{Ni}, \mathrm{Ag}$ и Al. Показано, что примесные атомы являются эффективными «ловушками» для сравнительно быстро мигрирующих в кристалле межузельных атомов. При взаимодействии межузельного атома и атома примеси межузельный атом формирует гантельную конфигурацию с осью вдоль направления $<100>$, а примесной атом располагается в ближайшей октаэдрической поре. Для анализа влияния примесей на диффузионную подвижность межузельных атомов были рассчитаны значения энергии активации миграции межузельного атома в чистых металлах и металлах, содержащих 10\% примесных атомов. Было выяснено, что подвижность межузельных атомов существенно снижается из-за наличия примесей в металле. При этом также снижался вклад краудионного механизма.

Ключевые слова: молекулярная динамика, металл, межузельный атом, примесь, энергия связи. 


\section{Introduction}

Interaction of impurity atoms with metals is of a significant scientific and technological interest, which has a wide range of applications in materials science. Atoms of light elements (primarily the most common ones: hydrogen, oxygen, nitrogen, carbon), forming interstitial defects and phases in metals, have high chemical activity and already at low concentrations strongly influence the properties of metals. Being effective traps for vacancies, dislocations and grain boundaries, the impurities of light elements significantly increase strength, hardness, frictional properties, as a rule, simultaneously with brittleness $[1,2]$. A high melting temperature and chemical resistance are typical for many interstitial alloys. Despite the importance of understanding the mechanisms and processes underlying the effect of doping light elements on the properties of metals, many questions now arise regarding the behavior of impurities at the atomic level in a metal matrix. In particular, the issues of interaction at the atomic level of various interstitial impurities with defects in the crystal lattice, especially dislocations and grain boundaries, remain insufficiently studied. In this case, computer simulation is an effective research tool.

Self-interstitials are not often considered as "traps" for impurity atoms. Nevertheless, according to the calculations carried out in $[3,4]$, they can also have a rather high binding energy with impurities close to the binding energy of an impurity with a vacancy and dislocations. For example, for $\alpha-\mathrm{Fe}$ and $\gamma$-Fe, the values of 0.68 and $0.58 \mathrm{eV}$, respectively, were obtained in [3]. Strictly speaking, in the case of interaction of impurity atoms and self-interstitials, it is more correct to call impurity atoms "traps", because self-interstitials are much more mobile than $\mathrm{C}, \mathrm{N}$ or O atoms in the metal lattice. Self-interstitial atoms have unique diffusion mobility. The activation energy of self-interstitials migration is significantly lower than the migration energy of other point defects $[5,6]$. The mechanism of self-interstitial migration is ambiguous and even in a pure crystal it has at least two variants: dumbbell and crowdion mechanisms $[7,8]$.

This work is devoted to the study of the interaction of impurity atoms of light elements $\mathrm{C}, \mathrm{N}$ and $\mathrm{O}$ with selfinterstitials in metals with an fcc lattice using molecular dynamics modeling. $\mathrm{Ni}, \mathrm{Ag}$ and $\mathrm{Al}$ were chosen as metals for the studies. This set of three metals is unique in that two of them have almost the same radii of atoms, while the other two have almost identical electronegativity. The radii of atoms: $\mathrm{Al}-1.43 \AA, \mathrm{Ag}-1.44 \AA, \mathrm{Ni}-1.24 \AA$ [1]. Electronegativity (on the Pauling scale): $\mathrm{Al}-1.61, \mathrm{Ag}-1.93, \mathrm{Ni}-1.91$ [9]. Thus, when obtaining different dependencies for these three metals, the relationship either with the size of the atoms or with the electronegativity will be seen.

\section{Description of the model}

The simulation was performed using the molecular dynamics method. The computational cell of the crystal had a shape of a parallelepiped and contained 8400 atoms. Periodic boundary conditions were used. The interactions of metal atoms with each other were described by the tight-binding Cleri-Rosato potentials [10]. To describe the interactions of impurity atoms of light elements with metal atoms and impurity atoms with each other, the Morse potential was chosen. The Cleri-Rosato and Morse potentials have proven themselves in numerous calculations performed by the molecular dynamics method [11-14]. Pair potentials are relatively often used by various researchers to describe interatomic interactions in metal-impurity systems. The parameters of the potentials for describing the interactions of impurity atoms $\mathrm{C}, \mathrm{N}$ and $\mathrm{O}$ with the metal atoms under consideration were taken from [15], where they were found taking into account empirical dependencies and known characteristics, such as melting or decomposition temperatures of the corresponding chemical compound of a metal with a light element, the activation energy of diffusion of an impurity atom in the crystal lattice of the metal. In [15], the potentials proposed by other authors were taken as a basis to describe the interactions of impurity atoms with each other in metals. For the $\mathrm{C}-\mathrm{C}$ bond, the pair potential from [16] was transformed into Morse potentials. For the N-N and O-O bonds, the potentials were taken from $[17,18]$.

\section{The mechanism of migration of a self-interstitial atom in an fcc crystal}

Self-interstitial atoms in the crystal lattice can have different non-equivalent positions. For example, in fcc crystals, up to six such positions are considered $[5,19]$ : in octahedral and tetrahedral pores, as a dumbbell (two atoms in one node) along different directions $(\langle 100\rangle,<110\rangle$ or $<111\rangle)$ and in the form of crowdion (an excess atom in a close-packed atomic row). In [5], it was shown that the dumbbell configuration with the axis along $\langle 111\rangle$ is unstable and transforms into a dumbbell with the axis along $\langle 100\rangle$. In general, the most energetically favorable in the fcc crystal, according to numerous studies, is the dumbbell configuration with the axis along the $<100>$ direction $[5,19,20]$ (Fig. 1a). At the same time, computer simulations usually give small differences in the formation energies of various interstitial atom configurations [5,19] (usually not more than $0.1-0.4 \mathrm{eV}$, according to [5]), that speaks about possible transformations from one configuration to another, the probability of which increases with increasing temperature. Due to the ambiguity of the configuration of a self-interstitial at medium and, especially, at high temperatures, the atomic mechanism of its migration includes several possible variants.

For example, in the case of migration of an interstitial atom as a dumbbell, one of the atoms of the pair moves to the lattice node, and the other leaves and forms a new dumbbell pair with the third atom, pushing it out of its node $[7,8,21]$. The mechanism of migration of an interstitial atom in the $<100>$ dumbbell configuration is the translational displacement of the center of the dumbbell by one interatomic distance and the rotational movement of its axis by $90^{\circ}$ (Fig. 1a).

Another mechanism, called the crowdion [22-25], is a relay displacement of the compression region along the closepacked atomic row, resulting from the presence of an extra atom in this row (Fig. 1b). Diffusion occurs due to small displacements of each of the atoms of the crowdion along 
the close-packed row, so the speed of movement is high, and the activation energy of migration is small. In this case, it is assumed that the initial configuration of the interstitial atom is the metastable crowdion configuration, which is energetically less favorable than the $<100>$ dumbbell. This mechanism is often considered in the study of processes occurring during radiation damage to materials $[22,23,26]$.

The leading mechanism of migration of an interstitial atom can be found out by analyzing the trajectories of atomic displacements, which in each case have characteristic features. For the dumbbell configuration, the displacement of the dumbbell is equally probable in all twelve directions, such as $\langle 110\rangle$, whereas for the crowdion mechanism there are only two possible directions of migration of the interstitial atom - in both directions along the crowdion. That is, the probability that an interstitial atom makes two consecutive jumps in the same direction is approximately $1 / 12$ for the "dumbbell" mechanism, and $1 / 2$ for the crowdion mechanism. For three consecutive jumps, respectively: 1/144 and 1/4. Thus, the characteristic feature of the crowdion mechanism are the direct trajectories of atomic displacements, for the mechanism of displacement and rotation of the $<100>$ dumbbells - broken trajectories.

Fig. 2 a shows the example of the trajectories of atomic displacements as a result of the self-interstitial migration in

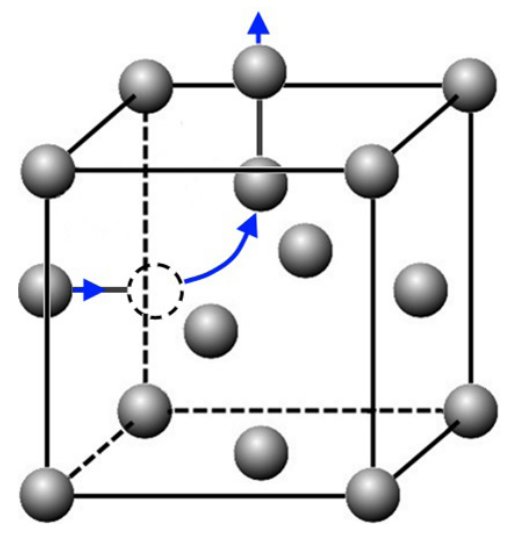

a pure $\mathrm{Ni}$ at a temperature close to the melting point. As can be seen, the trajectories contain both broken and straight-line sections along close-packed directions $\langle 110\rangle$, which testifies in favor of the implementation of the crowdion mechanism. Similar trajectories were observed during the migration of an interstitial atom in all pure fcc metals. Thus, a self-interstitial atom in pure fcc crystals migrates through not one, but at least two mechanisms discussed above.

It should be noted that after cooling the moleculardynamic models and relaxation of the structure, in all cases, the interstitial atoms formed a dumbbell configuration with the axis along $\langle 100\rangle$. Such a configuration, as mentioned above, is energetically the most favorable, while the crowdion configuration appears to be dynamic, i.e. temporary, and has a lifetime depending on temperature.

\section{Interaction of impurity atoms with a self-interstitial atom.}

When impurity atoms of light elements were introduced into models in the region of the self-interstitial atom, both defects, as a rule, formed the configuration shown in Fig. 3. The dumbbell of metal atoms remained in the same place, while the impurity atom displaced to the center of the nearest octahedral pore.

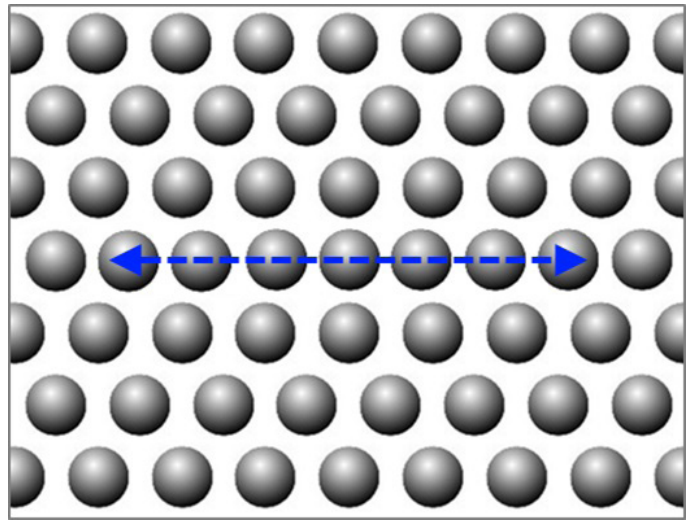

$\mathrm{b}$

Fig. 1. Mechanisms of migration of an interstitial atom in an fcc crystal: displacement and rotation of the $<100>$ dumbbell (a); the crowdion mechanism (b).

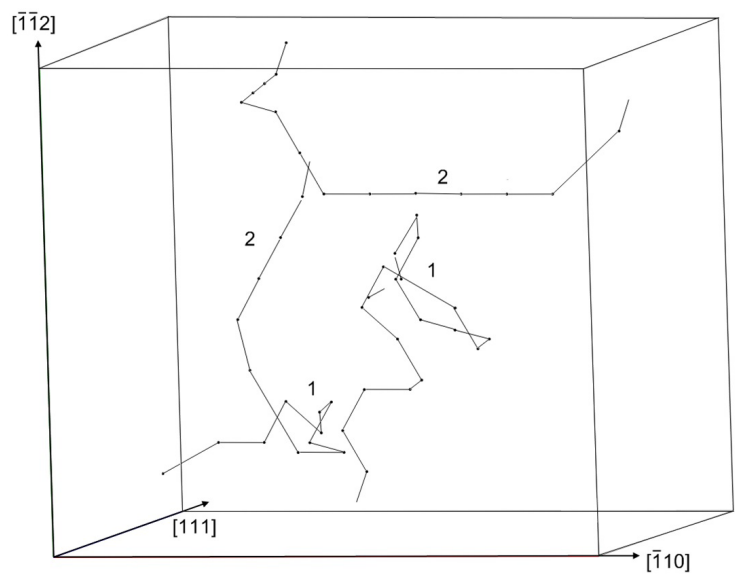

a

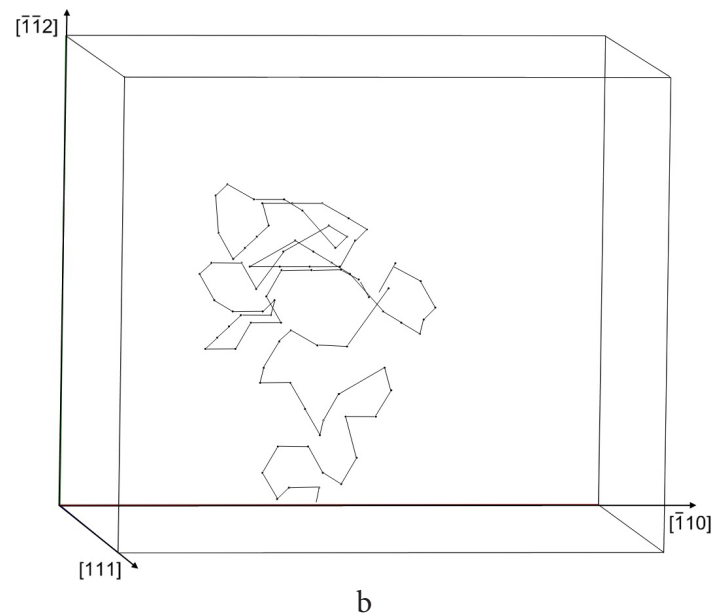

b

Fig. 2. Trajectories of atomic displacement as a result of the migration of an interstitial atom: in pure Ni at a temperature of $1700 \mathrm{~K}(0.98 \cdot \mathrm{Tm}$, where $\mathrm{Tm}$ is the melting temperature) for $50 \mathrm{ps}(1-$ the mechanism of displacement and rotation of the $<100>$ dumbbell; $2-$ the crowdion mechanism) (a); in Ni containing $10 \%$ of oxygen atoms at a temperature of $1700 \mathrm{~K}$ for $100 \mathrm{ps}$ (b). 
Table 1 shows the values obtained in the model for the binding energy of the impurity atom with the self-interstitial atom in the metals under consideration. The binding energy was calculated by the formula

$$
E_{b}=U_{0}-U
$$

were $U_{0}$ is the potential energy of a computational cell containing an interstitial atom and an impurity atom at such a distance (as a rule, several dozen interatomic distances) from each other, which eliminates the interaction of the selfinterstitial and the impurity atom; $U$ is the potential energy of a computational cell containing an impurity atom near a selfinterstitial atom in the configuration as in Fig. 3. In both cases, the structure was relaxed before calculating the energy of the computational cell, after which the cell was cooled to $0 \mathrm{~K}$.

It should be noted that all values of the binding energy given in the Table 1 are positive and relatively large, which means that the self-interstitial atoms and impurity atoms effectively interact and inhibit the migration of each other. Moreover, since the interstitial atoms are much more mobile than the impurity atoms, it is more correct, perhaps, to say that the latter are "traps" for the interstitial atoms, and not vice versa.

To analyze the effect of impurities on the diffusion mobility of interstitial atoms, we calculated the activation energy of the migration of an interstitial atom in pure metals and metals containing $10 \%$ impurity atoms. To determine the migration energy, we used the dynamic method [5], which consists in finding the dependence of the diffusion coefficient on temperature $D(T)$ when a certain number of defects of the considered type are introduced into the computational cell. Due to the presence of at least two migration mechanisms of the interstitial atom, dumbbell and crowdion, as well as the complexity of the migration mechanism in the case of the presence of impurities in the crystal, the diffusion activation energy, determined by the slope of the $\ln D$ dependence on $T^{-1}$, is in this case averaged. The results are shown in Table 2.

The migration energy of self-interstitial atoms in pure metals is very low, which causes their high diffusion mobility. For comparison, in works $[6,19,27]$, the following data, mainly by computer simulation, were obtained: $0.04-0.15 \mathrm{eV}$ in $\mathrm{Ni}, 0.05-0.12 \mathrm{eV}$ in $\mathrm{Ag}$ and $0.03-0.1 \mathrm{eV}$ in $\mathrm{Al}$.

As can be seen from Table 2, the mobility of interstitial atoms is significantly reduced due to the presence of impurities in the metal. With the introduction of $10 \%$ of impurity atoms, the migration energy of interstitial atoms increased several times. At the same time, the contribution of the crowdion mechanism also changes - it becomes noticeably smaller, which is clearly seen, for example, by a decrease in the number of straight sections on the migration trajectory of interstitial atoms (Fig. 2 b). The decrease in the contribution of the crowdion mechanism is associated with lattice distortions caused by impurity atoms.

Table 1. The binding energy of an impurity atom with a self-interstitial atom $(\mathrm{eV})$.

\begin{tabular}{|c|c|c|c|}
\hline & $\mathrm{C}$ & $\mathrm{N}$ & $\mathrm{O}$ \\
\hline $\mathrm{Ni}$ & 0.43 & 0.53 & 0.63 \\
\hline $\mathrm{Ag}$ & 0.22 & 0.23 & 0.29 \\
\hline $\mathrm{Al}$ & 0.86 & 0.66 & 0.45 \\
\hline
\end{tabular}

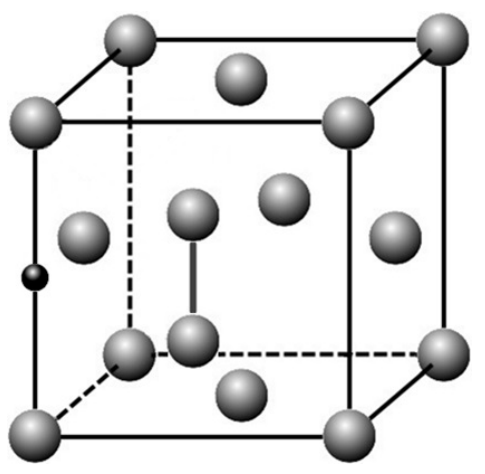

Fig. 3. The position of an impurity atom near a self-interstitial atom (in the form of a dumbbell along the $<001>$ direction) in an fcc lattice. The positions of the atoms are given without taking into account the relaxation of the structure.

Table 2. The migration energy of an interstitial atom in a pure metal and in the presence of $10 \%$ of impurity atoms $(\mathrm{eV})$.

\begin{tabular}{|c|c|c|c|c|}
\hline & Pure metal & $\mathrm{C}$ & $\mathrm{N}$ & $\mathrm{O}$ \\
\hline $\mathrm{Ni}$ & 0.09 & 0.38 & 0.30 & 0.34 \\
\hline $\mathrm{Ag}$ & 0.07 & 0.17 & 0.20 & 0.19 \\
\hline $\mathrm{Al}$ & 0.05 & 0.22 & 0.16 & 0.14 \\
\hline
\end{tabular}

\section{Conclusion}

The interaction of impurity atoms of light elements C, N, O with self-interstitials in fcc metals $\mathrm{Ni}, \mathrm{Ag}$ and $\mathrm{Al}$ was studied by the molecular dynamics method. It is shown that the self-interstitial atom in fcc metals migrates through at least two mechanisms: by the displacement and rotation of the $<100>$ dumbbell and by the crowdion mechanism. The first mechanism is characterized by broken trajectories of atomic displacements, the second - by straight ones along closepacked directions in the crystal.

The binding energies of impurity atoms with selfinterstitials in $\mathrm{Ni}, \mathrm{Ag}$ and $\mathrm{Al}$ are calculated. It is shown that impurity atoms are effective "traps" for interstitial atoms that migrate relatively quickly in the crystal. When a selfinterstitial atom and an impurity atom interact, the interstitial atom forms a dumbbell configuration with the axis along the $<100>$ direction, and the impurity atom is located in the nearest octahedral pore.

To analyze the effect of impurities on the diffusion mobility of interstitial atoms, we calculated the activation energy of migration of the interstitial atom in pure metals and metals containing $10 \%$ impurity atoms. It was found that the mobility of interstitial atoms is significantly reduced due to the presence of impurities in the metal. With the introduction of $10 \%$ of impurity atoms, the migration energy of interstitial atoms increased several times. At the same time, the contribution of the crowdion mechanism decreased.

\section{Литература/References}

1. H.J. Goldschmidt. Interstitial Alloys. London, Butterworths (1967) $640 \mathrm{p}$.

2. L.E. Toth. Transition metal carbides and nitrides. New York, Academic Press (1971) 276 p.

3. B. J. Lee. Acta Materialia. 54, 701 (2006). Crossref 
4. C. Domain, C. S. Becquart, J. Foct. Physical Revew B. 69, 144112 (2004). Crossref

5. G. M. Poletaev, M.D. Starostenkov. Physics of the Solid State. 52 (6), 1146 (2010). Crossref

6. S. Mahmoud, M. Trochet, O.A. Restrepo, N. Mousseau. Acta Materialia. 144, 679 (2018). Crossref

7. Yu. N. Osesky, A. Serra, V. Priego, F. Gao, D. J. Bacon. MRS Online Proceeding Library. 527, 49 (1998). Crossref

8. S. Bukkuru, U. Bhardwaj, S.K. Rao, A.D. P. Rao, M. Warrier, M.C. Valsakumar. Materials Research Express. 5 (3), 035513 (2018). Crossref

9. L. Pauling. The Nature of the Chemical Bond, Third Edition. Ithaca, Cornell University Press (1960) 664 p.

10. F. Cleri, V. Rosato. Physical Review B. 48 (1), 22 (1993). Crossref

11. D. V. Novoselova, G. M. Poletaev, V.V. Kovalenko. Letters on Materials. 8 (1), 11 (2018). (in Russian) [Д.В. Новоселова, Г. М. Полетаев, В.В.Коваленко. Письма о материалах. 8 (1), 11 (2018).] Crossref

12. G. Poletaev, I. Zorya, R. Rakitin. Computational Materials Science. 148, 184 (2018). Crossref

13. G.M. Poletaev, I. V. Zorya, D.V. Novoselova, M.D. Starostenkov. International Journal of Materials Research. 108 (10), 785 (2017). Crossref

14. G. M. Poletaev, M.D. Starostenkov. Technical Physics Letters. 29 (6), 454 (2003). $\underline{\text { Crossref }}$

15. I. V. Zorya, G. M. Poletaev, M.D. Starostenkov. Fundamental'nye problemy sovremennogo materialovedenia. 15 (4), 526 (2018) (in Russian) [И.В. Зоря, Г.М. Полетаев, М.Д. Старостенков. Фундаментальные проблемы современного материаловедения. 15 (4), 526 (2018).] Crossref

16. M. Ruda, D. Farkas, G. Garcia. Computational Materials Science. 45, 550 (2009). Crossref

17. P. Vashishta, R. K. Kalia, A. Nakano, J. P. Rino. Journal of
Applied Physics. 103, 083504 (2008). $\underline{\text { Crossref }}$

18. M.A. San Miguel, J. F. Sanz. Physical Review B. 58, 2369 (1998). Crossref

19. H. J. Wollenberger. Tochechnyye defekty. In: Fizicheskoye metallovedeniye. Vol. 3. Fizikomekhanicheskiye svoystva metallov i splavov. Ed. by R. W. Cahn. Moscow, Mir (1987) P. 5-74. (in Russian) [Волленбергер Г.Й. Точечные дефекты. В кн.: Физическое металловедение. Т. 3. Физикомеханические свойства металлов и сплавов.Под ред. Р. Кана. Москва, Мир (1987) С. 5 - 74.]

20. P. Zhao, Y. Shimomura. Computational Materials Science. 14, 84 (1999). Crossref

21. V. V. Kirsanov. Sorosovskiy obrazovatelniy zhurnal. 7 (9), 103 (2001). (in Russian) [В. В. Кирсанов. Соросовский образовательный журнал. 7 (9), 103 (2001).]

22. V. A. Stepanov. Technical Physics. The Russian Journal of Applied Physics. 43 (8), 938 (1998).

23. T. Amino, K. Arakawa, H. Mori. Scientific Reports. 6, 26099 (2016). Crossref

24. S. V. Dmitriev, N.N. Medvedev, A.P. Chetverikov, K. Zhou, M.G. Velarde. Phys. Status Solidi RRL. 11, 1700298 (2017). Crossref

25. A.M. Bayazitov, E.A. Korznikova, I.A. Shepelev, A.P. Chetverikov, S.Kh. Khadiullin, E.A. Sharapov, P. V. Zakharov, S. V. Dmitriev. IOP Conf. Series: Materials Science and Engineering. 447, 012040 (2018). Crossref

26. A. V. Korchuganov, K.P. Zolnikov, D.S. Kryzhevich, S. G. Psakhie. Russian Physics Journal. 60, 170 (2017). Crossref

27. A.N. Orlov, Y.V. Trushin. Energies of point defects in metals. Moscow, Energoatomizdat (1983) 80 p. (in Russian) [А.Н. Орлов, Ю.В. Трушин. Энергии точечных дефектов в металлах. Москва, Энергоатомиздат (1983) 80 c.] 